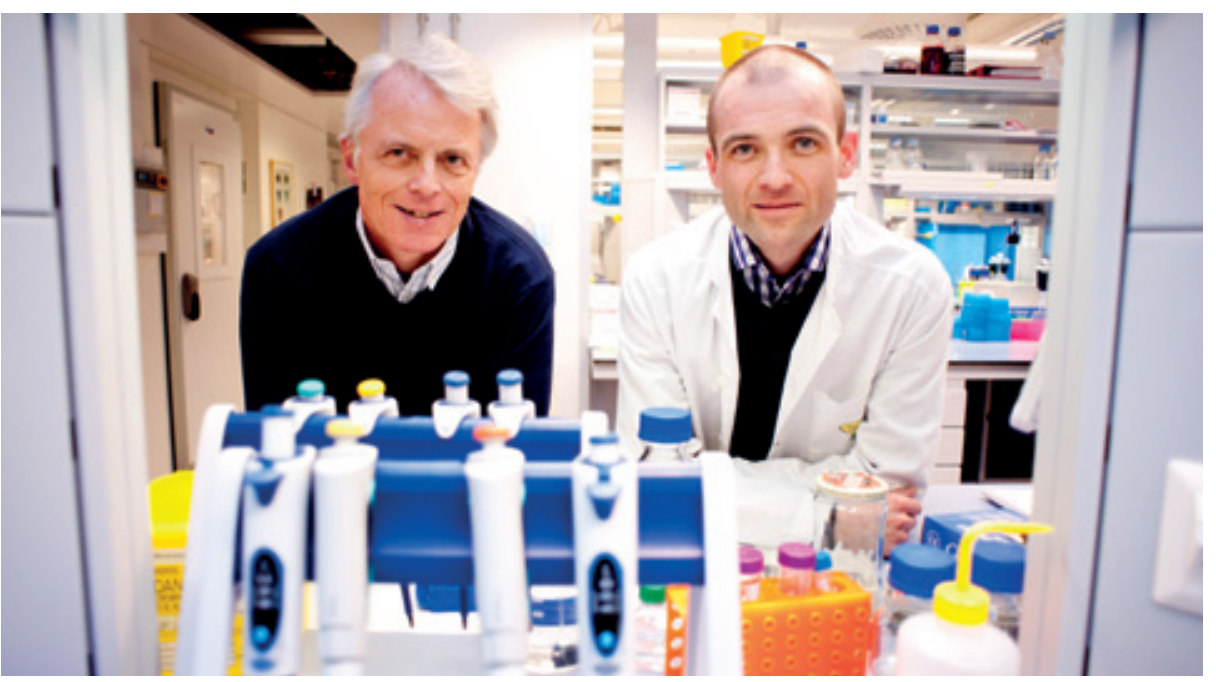

Stian Knappskog og Per Eystein Lønning, studiens første- og sisteforfatter. Foto Ole-Christian Amundsen, Haukeland universitetssykehus

\title{
Genvariant beskytter mot kreft
}

En nyoppdaget enkeltbasevariant har beskyttende effekt på brystkreft

\author{
og ovariekreft. Det viser ny norsk forskning.
}

MDM2-proteinet binder seg til og hemmer aktiviteten til p53-proteinet, som er helt sentralt for cellens evne til å stoppe cellesyklus og/eller undergå apoptose. Amplifisering av MDM2-genet eller MDM2-hyperaktivitet forårsaket av andre mekanismer, er påvist i mange typer svulster. Det er antatt at dette fenomenet kan substituere for mutasjoner i TP53-genet (som koder for p53proteinet) og forårsake en malign fenotype.

I 2004 publiserte en amerikansk forskergruppe oppdagelsen og karakteriseringen av en enkeltnukleotidpolymorfisme (SNP) i promotoren av MDM2-genet. Denne ble kalt SNP309 og besto $i$ at et T-nukleotid var erstattet av en G. G-varianten gir økt bindingsstyrke mellom MDM2-promotoren og transkripsjonsfaktoren $\mathrm{Sp} 1$, noe som igjen fører til økt uttrykking av MDM2-proteinet. Etter dette har det kommet flere studier som indikerer at bærere av 309G-allelet har høyere risiko for flere ulike kreftformer enn 309T-bærere. Imidlertid har man i noen studier, særlig fra Europa, kommet til et annet resultat.

Norske forskere har nå påvist en ny enkeltbasevariant, 285G $>$ C, i MDM2-promotor-regionen (1). Ved sensitive in vitroassays reduserte denne enkeltbasevarianten bindingstyrken til transkripsjonsfaktoren $\mathrm{Sp} 1$ og er dermed en antagonist til SNP309G. Den nyoppdagede enkeltbasevarianten forekom hos $7,8 \%$ av friske nordmenn, nederlendere og briter, men hos bare 1,6\% av finner og manglet helt hos kinesere, sier sisteforfatter Per Eystein Lønning ved Haukeland universitetssykehus.

- Våre funn tyder på at den nyoppdagede genvarianten har en beskyttende effekt mot kreft. Vi undersøkte om lag 2000 brystkreftpasienter, 2000 ovariekreftpasienter og 3600 friske kontrollpersoner og fant at SNP285C reduserte risikoen for brystkreft med $21 \%$ og for ovariekreft med $26 \%$. Effekten på ovariekreftrisikoen var særlig uttalt hos dem som var bærere av SNP309TG-genotype, sier Lønning.

\section{Forskning på brystkreft og ovariekreft}

Studien ble initiert og ledet av postdoktor Stian Knappskog og professor Per Eystein Lønning ved Mohn kreftforskningslaboratorium ved Haukeland universitetssykehus. Av flere kliniske samarbeidspartnere spilte stipendiat Merete Bjørnslett og overlege Anne Dørum ved Radiumhospitalet en nøkkelrolle med sine store kohorter av ovariekreftpasienter, som var helt avgjørende for å kunne påvise effekt på kreftrisiko av SNP285C. Dette samarbeidet er spennende fordi brystkreft og ovariekreft har flere felles molekylærbiologiske trekk. I tillegg har flere miljøer i Bergen, Oslo, Trondheim, Leiden, Helsinki, Beijing og Manchester bidratt med pasient- og kontrollmaterialer. De nasjonale biobankene var også svært viktige.

\section{Erlend Hem}

erlend.hem@medisin.uio.no

Tidsskriftet

\section{Litteratur}

1. Knappskog S, Bjørnslett M, Myklebust LM et al. The MDM2 promoter SNP285C/309G haplotype diminishes Sp1 transcription factor binding and reduces risk for breast and ovarian cancer in Caucasians. Cancer Cell 2011; 19: 273-82.
Ordforklaringer

MDM2 (Mouse Double Minute 2 homolog) er

et protoonkogen som ved hyperaktivitet bidrar til for lave nivåer av p53-proteinet, og dermed til redusert evne hos celler til å respondere adekvat på DNA-skade, f.eks. ved å gå i apoptose eller cellesyklusarrest.

Enkeltnukleotidpolymorfisme (single nucleotide polymorphism, SNP), også kalt enkeltbasevariasjon, er DNA-sekvensvariasjon som består $\mathrm{i}$ at et enkelt nukleotid ( $\mathrm{A}, \mathrm{T}, \mathrm{G}$ eller $\mathrm{C}$ ) i et individs genom er byttet ut med et annet.

Transkripsjonsfaktor er en faktor som binder et gens promotor og bidrar til transkripsjon (uttrykking) av genet.

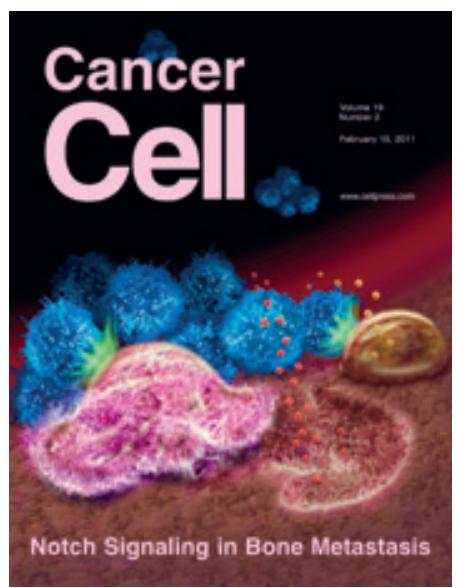

$>$ Artikkelen ble publisert 15.2. 2011 i Cancer Cell (www.cell.com/ cancer-cell), som er et av de høyest rangerte tidsskriftene innen onkologi 